\title{
PHYLOGENETIC RELATIONSHIPS AMONG BRAZILIAN HOWLER MONKEYS, GENUS Alouatta (PLATYRRHINI, ATELIDAE), BASED ON $\gamma^{1}$-GLOBIN PSEUDOGENE SEQUENCES
}

\author{
Carla Maria Meireles ${ }^{1}$, John Czelusniak ${ }^{1}$, Stephen F. Ferrari ${ }^{2}$, Maria Paula Cruz \\ Schneider ${ }^{2}$ and Morris Goodman ${ }^{1}$
}

\begin{abstract}
The genus Alouatta (howler monkeys) is the most widely distributed of New World primates, and has been arranged in three species groups: the Central American Alouatta palliata group and the South American Alouatta seniculus and Alouatta caraya groups. While the latter is monotypic, the $A$. seniculus group encompasses at least three species $(A$. seniculus, $A$. belzebul and $A$. fusca). In the present study, approximately 600 base pairs of the $\gamma^{1}$-globin pseudogene were sequenced in the four Brazilian species ( $A$. seniculus, $A$. belzebul, $A$. fusca and $A$. caraya). Maximum parsimony and maximum likelihood methods yielded phylogenetic trees with the same arrangement: $\{A$. caraya [A. seniculus ( $A$. fusca, $A$. belzebul)]\}. The most parsimonious tree had bootstrap values greater than $82 \%$ for all groupings, and strength of grouping values of at least 2 , supporting the sister clade of $A$. fusca and $A$. belzebul. The study also confirmed the presence of a 150-base pair Alu insertion element and a 1.8-kb deletion in the $\gamma^{1}$-globin pseudogene in $A$. fusca, features found previously in the remaining three species. The cladistic classification based on molecular data agrees with those of morphological studies, with the monospecific $A$. caraya group being clearly differentiated from the $A$. seniculus group.
\end{abstract}

\section{INTRODUCTION}

The systematics of the New World monkeys (infraorder Platyrrhini) has undergone considerable revision during the past two decades, but remains controversial (e.g. Rosenberger, 1984; Ford, 1986; Kay, 1990). Nevertheless, recent studies of DNA sequences (Schneider et al., 1993, 1996; Harada et al., 1995; Goodman, 1996; Barroso et al., 1997) have consistently supported an arrangement which recognizes only 15 genera, distributed in three families: Atelidae, Pitheciidae and Cebidae. Following this arrangement, the Atelidae encompasses four genera: Alouatta (howler monkeys), Ateles (spider monkeys), Brachyteles (muriquis) and Lagothrix (woolly monkeys). Relationships within the ateline clade - Ateles, Brachyteles and Lagothrix - have been disputed, but there is a growing consensus on the grouping of Brachyteles and Lagothrix, including conclusive evidence from gamma $(\gamma)$-globin gene sequences (Meireles et al., 1999). With one exception (Kay, 1990), there is also a general consensus on the distinct position of Alouatta, which is placed separately in either its own tribe, Alouattini (Rosenberger, 1984; Ford, 1986), or subfamily, Alouattinae (Hill, 1962; Napier and Napier, 1967; Hershkovitz, 1977).

Alouatta is the most widely distributed Neotropical primate genus (Neville et al., 1988), ranging from

\footnotetext{
${ }^{1}$ Department of Anatomy and Cell Biology, Wayne State University School of Medicine, 550 East Canfield Ave. MRB 422, Detroit, MI 48201, USA. Send correspondence to C.M.M. Fax: +1-313-577-1080. E-mail: carla@ns.med.wayne.edu.

${ }^{2}$ Departamento de Genética, CCB, Universidade Federal do Pará, Caixa Postal 8607, 66.075-900 Belém, PA, Brasil.
}

southern Mexico to northern Argentina, and is found in tropical and subtropical forest ecosystems throughout Brazil (Hirsch et al., 1991). Hershkovitz (1949) recognized three species groups based on the structure of the hyoid apparatus: the Central American Alouatta palliata group, and the South American Alouatta seniculus and Alouatta caraya groups. While the latter group is monotypic, the other two encompass a variety of different forms, whose arrangement has been subject to conflicting interpretations (e.g. Hershkovitz, 1949; Hill, 1962; Mittermeier et al., 1988; Groves, 1993; Bonvicino et al., 1995; Stanyon et al., 1995; Rylands and Brandon-Jones, 1998).

Despite the need for further work, especially on the integration of genetic and morphological data, the most recent major revisions of the genus (Hershkovitz, 1949; Hill, 1962) all divide the $A$. seniculus group into three species: A. seniculus, A. belzebul (endemic to Brazil) and A. (guariba) fusca. Groves (1993) does recognize a fourth species, Alouatta sara, but it is endemic to Bolivia, and thus not relevant to the present study. More recent studies (Bonvicino et al., 1995) also allocate species status to a number of subspecific forms of both A. seniculus and $A$. belzebul, but in the absence of a consensus, the arrangement of Groves (1993) will be followed here.

In addition to other unresolved questions, the karyotype of Alouatta varies from $2 \mathrm{n}=43$ to $2 \mathrm{n}=54$ (Armada et al., 1987; Lima and Seuánez, 1991; Stanyon et al., 1995). Of the four Brazilian species, only A. caraya has a fixed number of chromosomes, with $2 \mathrm{n}=52$ (Pargament et al., 1984), whereas in A. seniculus, $2 \mathrm{n}$ varies from 43 to 49 (Yunis et al., 1976; Lima and Seuánez, 1991). A. belzebul and $A$. fusca, on the other hand, share both the same diploid number $(2 \mathrm{n}=49 / 50)$ and a translocation on the Y chromosome (Koiffmann and Saldanha, 1974; Armada et al., 1987). 
In humans, the $\gamma$-globin gene is located on the short arm of chromosome 11 (Lebo et al., 1979; Bunn and Forget, 1986). This gene is expressed embryonically in strepsirrhine primates (Tagle et al., 1988), but was duplicated in tandem in anthropoids $\left(\gamma^{1}\right.$ and $\left.\gamma^{2}\right)$, becoming expressed fetally (Fitch $e t$ al., 1991). This globin gene is part of the beta $(\beta)$-globin gene cluster, which in primates includes the $\varepsilon, \gamma, \psi \eta, \delta$ and $\beta$ globin genes (Figure 1). All genes in this cluster have three exons and two introns (Lawn et al., 1980). In the atelids, $\gamma^{1}$ is a pseudogene (Meireles et al., 1995, 1998), whereas in the platyrrhine genera Aotus and Saimiri, the two loci are combined into a hybrid gene (Chiu et al., 1996).

Several recent studies (Schneider et al., 1993, 1996; Harada et al., 1995; Porter et al., 1995, 1997a,b; Meireles et al., 1999) have used DNA sequences of the globin gene to resolve phylogenetic relationships in the platyrrhines, producing results generally consistent with those of more traditional morphological studies in most (see Schneider and Rosenberger, 1996), but not all (Shoshani et al., 1996) cases. In the present study, sequences of the $\gamma^{1}$-globin pseudogene were used in a molecular analysis of the phylogenetic relationships among Brazilian howler monkeys. The aligned sequences were also used to estimate divergence times based on a local molecular clock, and to investigate the presence of the Alu insertion - found in other Alouatta species (Meireles et al., 1995, 1998) - in A. fusca.

\section{MATERIAL AND METHODS}

\section{Study species}

Howler monkeys are large-bodied, prehensile-tailed platyrrhines more specialized for folivory than frugivory, as is typical of other atelids. They are also highly sexually dimorphic in body size (adult males are 70-80\% heavier than females), and two of the Brazilian species (A. caraya and $A$. fusca) are among only three platyrrhines (the other is Pithecia pithecia) to exhibit sexual dimorphism in pelage coloration (Mittermeier et al., 1988). A. belzebul also exhibits the most marked individual variation in pelage coloration of any platyrrhine (Bonvicino et al., 1989). Only one species (A. belzebul) is endemic to Brazil, but it is also the only one found in both Amazonian and Atlantic forest biomes. The remaining three species are found in Amazonia (A. seniculus), the Brazilian Atlantic forest and neighboring areas (A. fusca), and the savanna and swampy habitats of central and western Brazil (A. caraya).

\section{Preparation and amplification of DNA}

Genomic DNA was extracted from the peripheral blood cells of captive specimens of the four Brazilian howler monkey species (Table I), and the $\gamma^{1}$-globin sequences for A. caraya, A. belzebul and A. seniculus were determined by C.M.M. (Meireles, 1997). DNA extraction for $A$. caraya and A. seniculus was based on the protocol of Bell et al. (1981), whereas for A. belzebul and A. fusca, that of Sambrook et al. (1989) was used.

The $\gamma^{1}$ fragment was obtained using the PCR protocol described in Meireles et al. (1995), and consisted of an initial denaturation of $3 \mathrm{~min}$ at $94^{\circ} \mathrm{C}$ followed by 30 cycles of denaturation at $94^{\circ} \mathrm{C}(30 \mathrm{~s})$, annealing at $55^{\circ} \mathrm{C}$ $(45 \mathrm{~s})$, extension at $72^{\circ} \mathrm{C}(45 \mathrm{~s})$ and a final extension of 10 min at $72^{\circ} \mathrm{C}$. The amplification products were separated by agarose gel electrophoresis. The DNA primers (synthesized at the Center for Molecular Medicine and Genetics, Wayne State University, Detroit, USA) were:

R1 5' -AAT GTG GAA GAT GCT GGG- 3' and R2 5' -GTC ATG TCT GAG CAA CAA AC- 3'

Despite the presence of a $1.8-\mathrm{kb} \gamma^{1}$ deletion in all four species (Figure 1), these primers amplified a $\sim 600$-bp fragment in all cases.

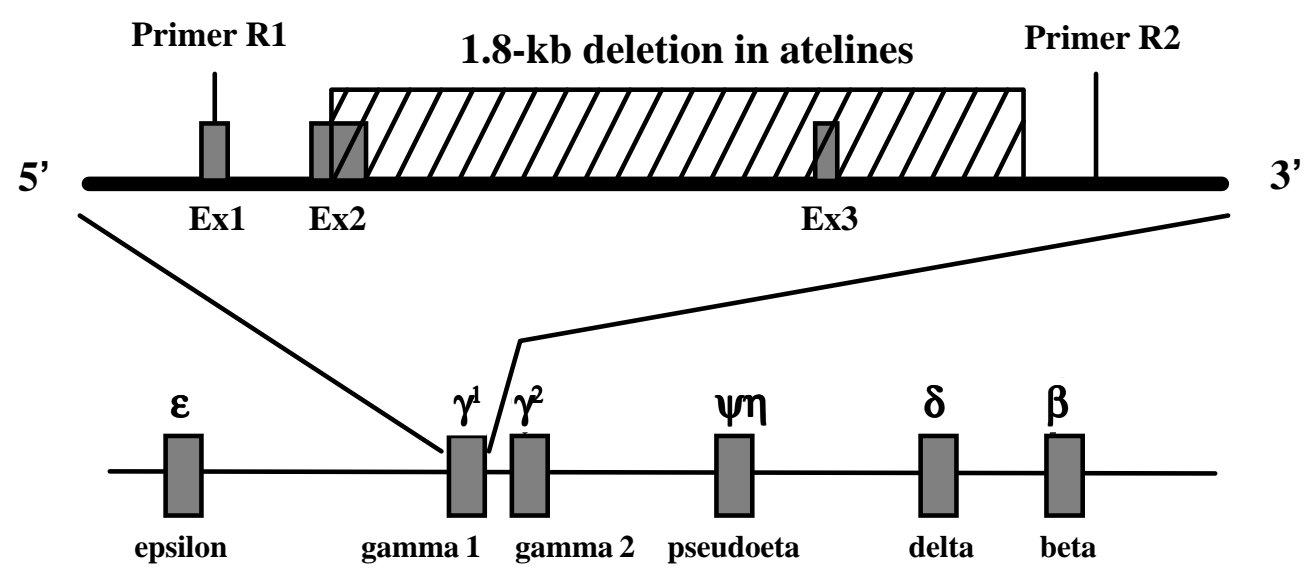

Figure 1 - Model of the $\beta$-cluster showing the five globin genes. The $\gamma^{1}$-globin pseudogene is amplified exhibiting the primers R1 and R2 used in this study and also the 1.8-kb deletion shared by all four Alouatta species as well as by the ateline group (Meireles et al., 1995, 1998). 
Table I - Code, origin and GenBank accession number for specimens analyzed in the present study.

\begin{tabular}{|lcccc|}
\hline Species & Code & Origin $^{\mathrm{a}}$ & $\begin{array}{c}\text { GenBank accession } \\
\text { number }\end{array}$ & Source $^{\mathrm{b}}$ \\
\hline Alouatta caraya & Aca & Los Angeles Zoo & AF030095 & 1 \\
Alouatta belzebul & Abe & CENP & AF030096 & 1 \\
Alouatta seniculus & Ase & Los Angeles Zoo & AF030097 & 1 \\
Alouatta fusca & Afu & CPRJ & AF068573 & 1 \\
Outgroups & & Unknown & M81409 & 2 \\
Cebus albifrons & Cal & Unknown & J03938 & 3 \\
Macaca mulatta & Mmu & Unknown & J00179 & 4 \\
Homo sapiens & Hsa & Como & \\
\hline
\end{tabular}

${ }^{a}$ CENP = Brazilian National Primate Center, Ananindeua, Pará; CPRJ = Rio de Janeiro Primate Center, Magé, Rio de Janeiro. ${ }^{b} 1$ = Present study; 2 = Hayasaka et al. (1993); 3 = Slightom et al . (1988); Fitch et al. (1991); 4 = Slightom et al. (1980); Shen et al. (1981); Rogan et al. (1987).

\section{Cloning of PCR products}

The PCR products were separated in $1.0 \%$ agarose gels in TBE buffer $(89 \mathrm{mM}$ Tris-base, $89 \mathrm{mM}$ boric acid and $2 \mathrm{mM}$ EDTA, $\mathrm{pH}$ 8.0) containing $0.5 \mu \mathrm{g}$ ethidium bromide/ml. The amplified fragments were excised and purified using a Qiaex II gel extraction kit (Qiagen). The purified DNA fragments were cloned into the pGEM-T vector system I (Promega) and transformed into Escherichia coli host JM109 (Promega) according to the protocol supplied by the vendors. Single-stranded DNA was prepared from selected clones using helper phage M13K07 (Promega) and purified by PEG-NaCl precipitation followed by phenolchloroform extraction and ethanol precipitation.

\section{Sequencing}

Nucleotide sequences were determined for at least three clones of each species by the dideoxy chain-termination method (Sanger et al., 1977) using a Sequenase version 1.0 kit (United States Biochemical). The sequences were aligned by eye using version 3.0 of the ESEE sequence editor (Cabot and Beckenbach, 1989). Gaps were inserted to minimize the number of nucleotide substitutions and indels (insertions/deletions) needed to account for the descent of the aligned sequences. As PCR reactions commonly result in slightly different sequences for the same cloned fragments, a consensus sequence of three or more clones was defined for each species. These consensus sequences were then aligned against the known orthologous sequences which represented the outgroups for the phylogenetic analysis: Cebus albifrons (Cal), Macaca mulatta (Mmu) and Homo sapiens (Hsa).

\section{Phylogenetic analysis}

Phylogenetic analyses were performed using the maximum parsimony and maximum likelihood methods. The most parsimonious and the maximum likelihood trees were determined using the phylogenetic analysis using parsimony (PAUP) parsimony program, version 4.0 for DOS (written by David Swofford, Smithsonian Institute, Washington, DC, USA). For both trees, the strength of grouping values or Bremer decay indices were estimated using the PAUP program, and bootstrap analysis was applied to test the support for each grouping. Two thousand bootstrap replications with one shuffle per replication were carried out on the seven data sets. The number of parsimony-informative characters (synapomorphies) was established by eye and confirmed by the PAUP program. Divergence times were estimated using the branch lengths of the maximum likelihood tree constructed from a distance matrix calculated using Kimura's (1980) model. The molecular clock was calibrated using the local clock procedure, based on Goodman's (1996) estimate of 21 MYA for the divergence between Cebus and Alouatta.

\section{RESULTS AND DISCUSSION}

\section{Analysis of $\gamma^{1}$-pseudogene sequences}

PCR amplification using the 5' R1 and 3' R2 primers produced two fragments for all four genera. The fragment corresponding to $\gamma^{1}$ contained approximately $600 \mathrm{bp}$, and that of $\gamma^{2}$ about $2100 \mathrm{bp}$ (Figure 2). The sequences indicated that this difference in size was due to a $\sim 1.8-\mathrm{kb}$ deletion at the $\gamma^{1}$ locus, which is shared by all four atelid genera (Meireles et al. 1995, 1998). These authors also encountered a $\sim 150$-bp insertion, described as a monomeric Alu element by Drs. Roy Britten (CIT, Pasadena, USA) and Jerzy Jurka (UC, Berkeley, USA), in A. caraya, A. belzebul and $A$. seniculus. In the present study, this same 150-bp Alu insertion was also found in A. fusca, indicating that it is an important synapomorphic marker for the analysis of Alouatta phylogeny and evolution. Figure 2 also shows a clear difference in the size of the $\gamma^{1}$-globin fragment in two representative atelid genera, Ateles $(\sim 450$ bp) and Alouatta ( 600 bp). 


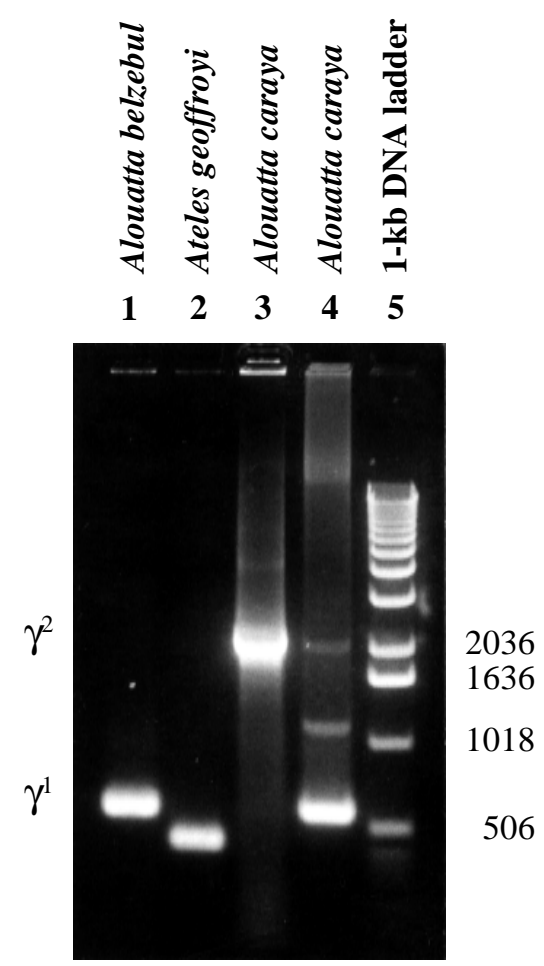

Figure 2 - PCR-amplified $\gamma$ gene DNA in atelids: $1-\gamma^{1}$ fragment of the purified PCR product of Alouatta belzebul; $2-\gamma^{1}$ fragment of the purified PCR product of Ateles geoffroyi; $3-\gamma^{2}$ fragment of the purified PCR product of Alouatta caraya; 4 - PCR products of the genomic DNA of Alouatta caraya; 5 - 1-kb DNA ladder.

The nucleotide sequences bordered by primers R1 and $\mathrm{R} 2$ in the seven primate species studied here spanned a total of 2,482 aligned base positions (Figure 3) consisting of the following $\gamma^{1}$ gene regions: the $5^{\prime}$ coding region of exon 1 (1-35), intron 1 (36-160), exon 2 (161-211), a $\sim 1.8$-kb deletion (212-2092), a region between the deletion and insertion (2093-2149), a 150-bp insertion (21502298), and the 3 ' flanking region (2299-2482). In the phylogenetic analysis, all sequences except that of $A$. fusca were also represented by a $1.8-\mathrm{kb}$ region extending upstream from the R1 primer. The sequences in this region are described in Meireles et al. (1999). The DNA sequences were deposited in GenBank (Table I), and are also available from the authors on request, or can be accessed via internet at http://ns.med.wayne.edu/.

\section{Phylogeny of Brazilian howler monkeys}

The maximum parsimony consensus tree (Figure 4), constructed using the PAUP program, had a nucleotide substitution score of 813 (length). The numbers above the lines show the minimum number of additional substitutions required to break up the clade (strength of grouping - SOG - value or Bremer decay index), while the numbers below the lines show the bootstrap values (number of times the grouping was encountered in 2,000 replicates) as percentages. The arrangement of howler species was: $\{$ A. caraya [A. seniculus (A. fusca, A. belzebul)]\}, with SOG values of 66,2 and 2 , respectively.

All bootstrap values were greater than the critical value of $75 \%$ proposed by Hillis and Bull (1993), with a minimum value of $82 \%$ for the A. seniculus-A. belzebul/A. fusca clade. The A. belzebul-A. fusca clade was supported by a value of $88 \%$, while $100 \%$ of the replications identified A. caraya as the basal species. The number of sharedderived sequence changes (synapomorphies) found by the PAUP analysis also supported this arrangement. The positions of the synapomorphies for the Alouatta species clades (Figure 3) were:

A. fusca $\times$ A. belzebul $-48(\mathrm{G} \rightarrow \mathrm{A}), 77(\mathrm{C} \rightarrow \mathrm{G}), 79(\mathrm{G} \rightarrow \mathrm{A})$ with homoplasy and $2318(\mathrm{~A} \rightarrow \mathrm{C})$ with homoplasy;

Alouatta species - $212(\mathrm{C} \rightarrow 1.8$-kb deletion), $2095(\mathrm{del} \rightarrow \mathrm{A})$, $2096(\mathrm{del} \rightarrow \mathrm{G}), 2117(\mathrm{~T} \rightarrow \mathrm{G}), 2145(\mathrm{G} \rightarrow \mathrm{T}), 2150(\mathrm{del} \rightarrow 150-$ bp Alu insertion), $2324(\mathrm{C} \rightarrow \mathrm{T})$ with homoplasy, $2335(\mathrm{C} \rightarrow \mathrm{T})$, $2349(\mathrm{C} \rightarrow \mathrm{G}), 2401(\mathrm{G} \rightarrow \mathrm{A}), 2403(\mathrm{G} \rightarrow \mathrm{A}), 2405(\mathrm{G} \rightarrow \mathrm{A})$, $2411(\mathrm{G} \rightarrow \mathrm{A}), 2416(\mathrm{~A} \rightarrow \mathrm{del})$ and $2451(\mathrm{C} \rightarrow \mathrm{T})$.

The natural logarithm (ln) of the likelihood for the best maximum likelihood tree using the aligned $\gamma$-globin sequences was -9329.13944. Bootstrap values (as a percentage of 2,000 replicates) are shown below the lines (Figure 5). Although the topologies of the tree and bootstrap values for the first (88) and last (100) clades were the same, the $A$. seniculus-A. belzebul/A. fusca clade had a borderline bootstrap value of 72 . This analysis confirmed the cladistic groupings shown by the maximum parsimony tree (Figure 4).

Although the A. belzebul-A. fusca clade was relatively well defined, with a high bootstrap value $(88 \%)$ and four shared synapomorphies, the analysis did not permit identification of the species closest to $A$. seniculus, despite the relative geographic proximity of $A$. belzebul in southwestern Amazonia (Hirsch et al., 1991). The data, nevertheless, supported the presence of a well-defined $A$. seniculus group [A. seniculus (A. belzebul, A. fusca)] as proposed by Hershkovitz (1949) and still widely accepted (e.g. Mittermeier et al., 1988). There is little doubt from these data that $A$. caraya should be placed in a distinct, monotypic group, and that Alouatta is monophyletic, with 15 synapomorphies.

The divergence times between the different Alouatta lineages (Table II) were calculated by the local molecular clock method, based on Goodman's (1996) estimate of 21 MYA for the split between Alouatta and Cebus, using the maximum likelihood branch lengths for the sequences of the $\gamma^{1}$-globin pseudogene. This analysis indicated that the different Alouatta lineages diverged relatively recently in relation to the putative \pm 11 MYA split of the alouattine and ateline groups (Meireles et al., 1999).

Overall, then, the results of the present study corroborate the phylogenetic relationships among Brazilian howler monkey species suggested by morphological characteristics (Mittermeier et al., 1988), principally the existence of distinct $A$. caraya and $A$. seniculus groups, which diverged approximately 2.5 MYA (Table II). 


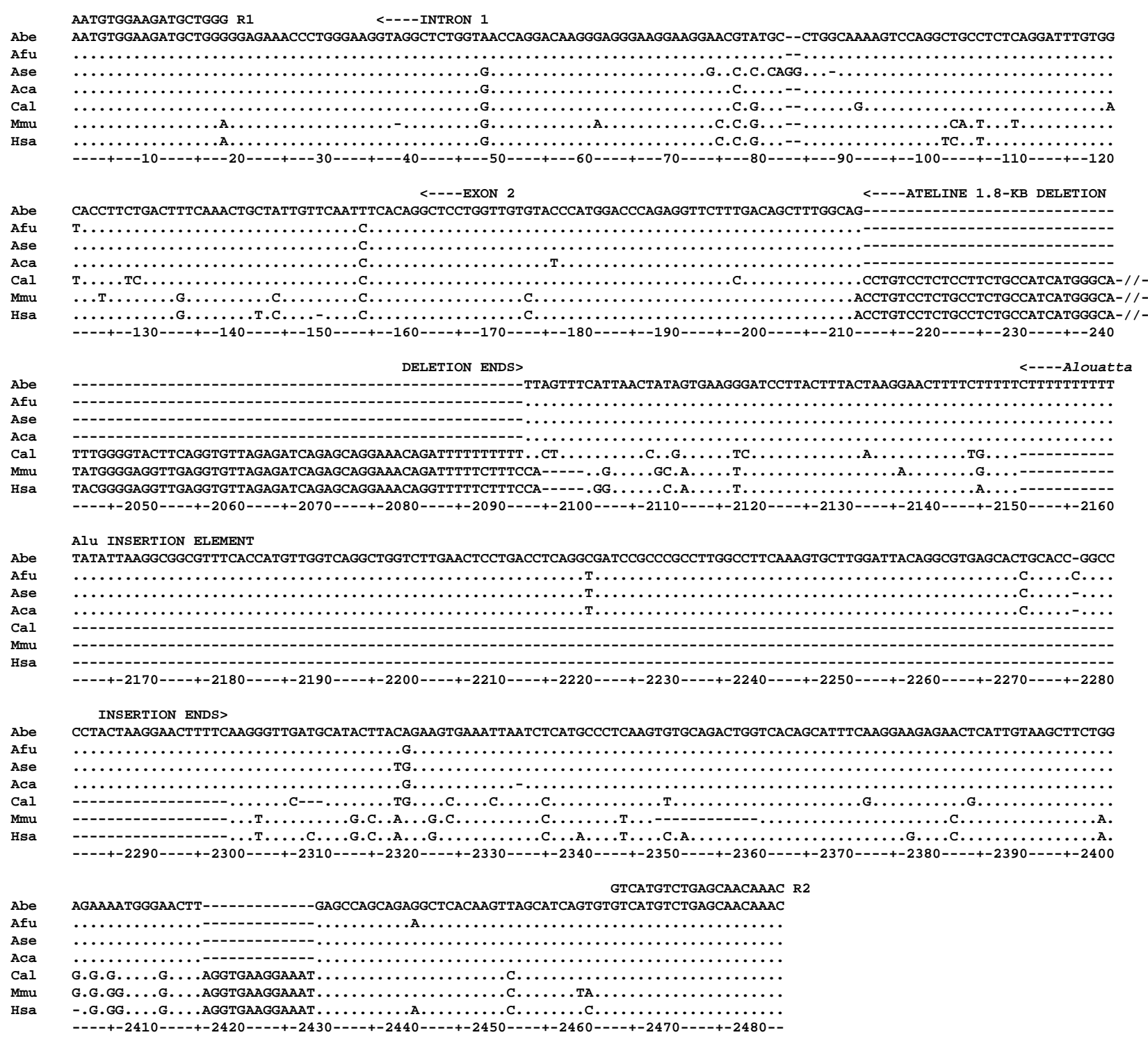

Figure 3 - Aligned DNA sequences of the $\gamma^{1}$-globin pseudogene corresponding to the region between the R1 and R2 primers in four simian genera, including four Alouatta species (see abbreviations in Table I). Dots indicate the same nucleotide as that found in the first (Abe) sequence, and dashes designate gaps resulting from insertions/deletions in the alignment. Sequences corresponding to positions 2041-3720 in Cebus albifrons (Cal), Macaca mulatta (Mmu) and Homo sapiens (Hsa) were published by Bailey et al. (1992) and are thus omitted here.

\section{Length $=813$}

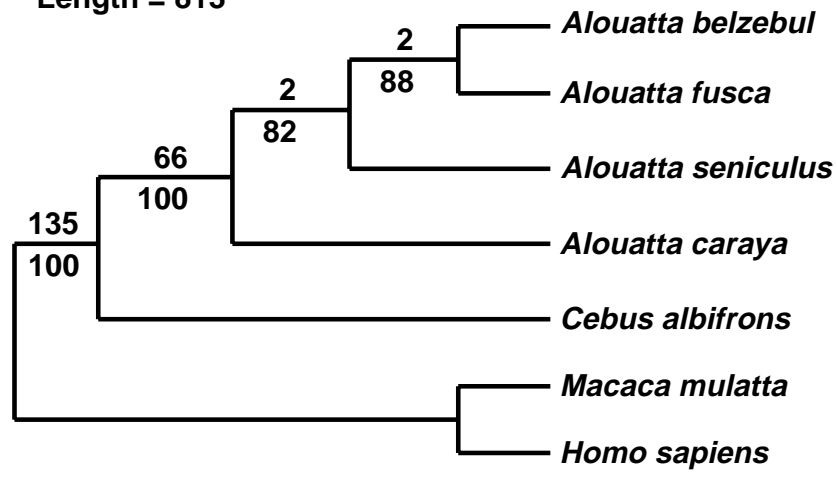

Figure 4 - Maximum parsimony tree derived from the aligned $\gamma^{1}$-globin nucleotide sequences in seven simian species. The length, or nucleotide substitution score, is 813 . Values above the lines represent the minimum number of additional substitutions required to break up the clade designated by that node and those below the lines, the percentage of bootstrap values obtained in 2,000 replicates. 


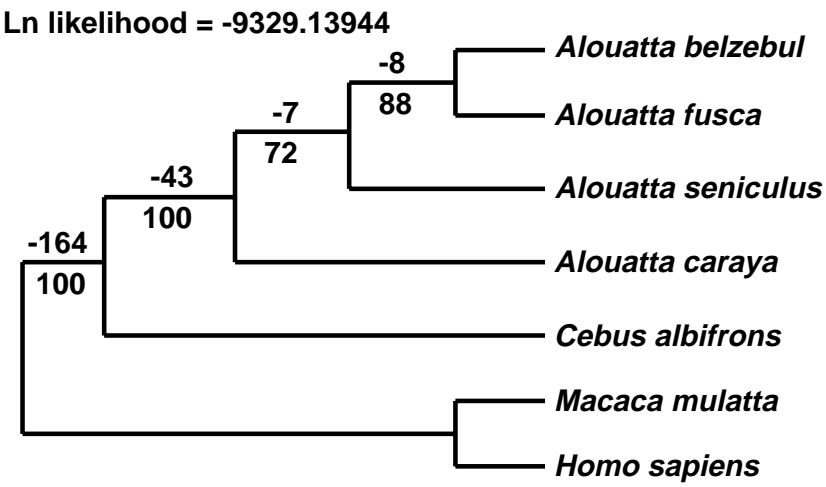

Figure 5 - Maximum likelihood tree derived from the aligned $\gamma^{1}$-globin nucleotide sequences in seven simian species. Log likelihood is -9329.13944. Values above the lines represent the minimum decrease in the log likelihood required to break up the clade designated by that node and those below the lines, the percentage of bootstrap values obtained in 2,000 replicates.

Table II - Local molecular clock estimates of the divergence times of Alouatta species lineages based on the maximum likelihood branch lengths and Goodman's (1996) estimate of the split between Alouatta and Cebus.

\begin{tabular}{|lcc|}
\hline Branching point & Mean branch length & Divergence (MYA) \\
\hline (A. fusca, A. belzebul) & 0.0029 & 1.0 \\
[A. seniculus (A. fusca, belzebul)] & 0.0040 & 1.5 \\
\{A. caraya $[$ A. seniculus $($ A. fusca, A. belzebul)]\} & 0.0047 & 2.4 \\
(Cebus, Alouatta) & 0.0383 & 21.0 \\
\hline
\end{tabular}

\section{ACKNOWLEDGMENTS}

We thank Dr. Kathy Neiswanger (University of Pittsburgh Medical Center, Pittsburgh, PA, USA), Adelmar Coimbra-Filho and Alcides Pissinatti (Centro de Primatologia do Rio de Janeiro, RJ, Brazil), and José A.P.C. Muniz (Centro Nacional de Primatas, Ananindeua, PA, Brazil) for the samples used in this study. We also thank Drs. Roy Britten (California Institute of Technology, Pasadena) and Jerzy Jurka (University of California, Berkeley) for classifying the monomeric Alu insertion of $150 \mathrm{bp}$ found in the Alouatta sequences. This research was supported by grants from Conselho Nacional de Desenvolvimento Científico e Tecnológico (CNPq), Brazil (No. 201530/93-7), National Institutes of Health (NIH), USA (No. HL33940) and the National Science Foundation (NSF), USA (No. DEB9116098).

\section{RESUMO}

Os guaribas, do gênero Alouatta, que são os primatas do Novo Mundo com maior distribuição geográfica, têm sido colocados em três grupos de espécies: o grupo Alouatta palliata da América central, e os grupos sulamericanos Alouatta seniculus e Alouatta caraya. Este último é monotípico, mas o grupo $A$. seniculus inclui pelo menos três espécies (A. seniculus, A. belzebul e $A$. fusca). Neste estudo, foram seqüenciados aproximadamente 600 pares de base do pseudogene globina $\gamma^{1}$ nas quatro espécies brasileiras (A. seniculus, A. belzebul, A. fusca e A. caraya). Os métodos de máxima parcimônia e máxima verossimilhança produziram árvores filogenéticas com o mesmo arranjo: $\{A$. caraya $[A$. seniculus (A. fusca, A. belzebul)]\}. A árvore mais parcimoniosa apresentou valores de bootstrap maiores de $82 \%$ para todos os agrupamentos, e valores de força de ligação de pelo menos 2, apoiando o agrupamento irmão de $A$. fusca e $A$. belzebul. O estudo também confirmou a presença em $A$. fusca do elemento de inserção $A l u$, com 150 pares de base, e uma deleção de $1,8 \mathrm{~kb}$ no pseudogene globina $\gamma^{1}$ já conhecidos nas demais espécies de guaribas. A classificação cladística baseada em dados moleculares é congruente com as de estudos morfológicos, com um isolamento claro do grupo monoespecífico $A$. caraya em relação ao grupo $A$. seniculus.

\section{REFERENCES}

Armada, J.L.A., Barroso, C.M.L., Lima, M.M.C., Muniz, J.A.P.C. and Seuánez, H.N. (1987). Chromosome studies in Alouatta belzebul. Am. J. Primatol. 13: 283-296.

Bailey, W.J., Hayasaka, K., Skinner, C.G., Kehoe, S., Sieu, L.C., Slightom, J.L. and Goodman, M. (1992). Reexamination of the African hominoid trichotomy with additional sequences from the primate $\beta$-globin gene cluster. Mol. Phylogenet. Evol. 1: 97-135.

Barroso, C.M.L., Schneider, H., Schneider, M.P.C., Sampaio, I., Harada, M.L., Czelusniak, J. and Goodman, M. (1997). Update on the phylogenetic systematics of New World monkeys: further DNA evidence for placing the pygmy marmoset (Cebuella) within the genus Callithrix. Int. J. Primatol. 18: 651-674.

Bell, G.I., Karam, J.H. and Rutter, W.J. (1981). Polymorphic DNA region adjacent to the 5' end of the human insulin gene. Proc. Natl. Acad. Sci. USA 78: 5759-5763.

Bonvicino, C.R., Langguth, A. and Mittermeier, R.A. (1989). A study of the pelage color and geographic distribution in Alouatta belzebul (Primates, Cebidae). Rev. Nordestina Biol. 6: 139-148.

Bonvicino, C.R., Fernandes, M.E.B. and Seuánez, H.N. (1995). Morphological analysis of Alouatta seniculus species group (Primates, Cebidae). A comparison with biochemical and karyological data. Hum. Evol. 10: 169-176.

Bunn, H.F. and Forget, B.G. (1986). Hemoglobin: Molecular, Genetic and Clinical Aspects. W.B. Saunders Company, Philadelphia. 
Cabot, E.L. and Beckenbach, A.T. (1989). Simultaneous editing of multiple nucleic acid and protein sequences with ESEE. Comput. Appl. Biosci. 5: 233-234.

Chiu, C.-H., Schneider, H., Schneider, M.P.C., Sampaio, I., Meireles, C.M., Slightom, J.L., Gumucio, D.L. and Goodman, M. (1996). Reduction of two functional $\gamma$-globin genes to one: an evolutionary trend in New World monkeys (Infraorder Platyrrhini). Proc. Natl. Acad. Sci. USA 93: 6510-6515.

Fitch, D.H.A., Bailey, W.J., Tagle, D.A., Goodman, M., Sieu, L. and Slightom, J.L. (1991). Duplication of the $\gamma$-globin gene mediated by L1 long interspersed repetitive elements in an early ancestor of simian primates. Proc. Natl. Acad. Sci. USA 88: 7396-7400.

Ford, S.M. (1986). Systematics of the New World monkeys. In: Comparative Primate Biology. Vol. 1. Systematics, Evolution, and Anatomy (Swindler, D.R. and Erwin, J., eds.). A.R. Liss, New York, pp. 73135.

Goodman, M. (1996). Epilogue: a personal account of the origins of a new paradigm. Mol. Phylogenet. Evol. 5: 269-285.

Groves, C.P. (1993). Order Primates. In: Mammal Species of the World: a Taxonomic and Geographic Reference (Wilson, D.E. and Reeder, D.M., eds.). Smithsonian Institution Press, Washington D.C., pp. 243277.

Harada, M.L., Schneider, H., Schneider, M.P.C., Sampaio, I., Czelusniak, J. and Goodman, M. (1995). DNA evidence on the phylogenetic systematics of New World monkeys: support for the sister-grouping of Cebus and Saimiri from two unlinked nuclear genes. Mol. Phylogenet. Evol. 4: 331-349.

Hayasaka, K., Skinner, C.G., Goodman, M. and Slightom, J.L. (1993). The $\gamma$-globin genes and their flanking sequences in primates: findings with nucleotide sequences of capuchin monkey and tarsier. Genomics 18: 20-28.

Hershkovitz, P. (1949). Mammals of northern Colombia. Preliminary report No. 4: monkeys (Primates), with taxonomic revisions of some forms. Proc. U.S. Nat. Mus. 98: 323-427.

Hershkovitz, P. (1977). Living New World Monkeys (Platyrrhini) with an Introduction to Primates. Vol. I. University of Chicago Press, Chicago.

Hill, W.C.O. (1962). Primates, Comparative Anatomy and Taxonomy. Vol. V. Cebidae. Part B. University Press, Edinburgh.

Hillis, D.M. and Bull, J.J. (1993). An empirical test of bootstrapping as a method of assessing confidence on phylogenetic analysis. Syst. Biol. 42: 182-192.

Hirsch, A., Landau, E.C., Tedeschi, A.C.M. and Menegheti, J.O. (1991). Estudo comparativo das espécies do genero Alouatta Lacépède, 1799 (Platyrrhini, Atelidae) e sua distribuição geográfica na América do Sul. In: A Primatologia no Brasil. Vol. 3 (Rylands, A.B. and Bernardes, T.A., eds.). Fundação Biodiversitas, Belo Horizonte, pp. 239-262.

Kay, R.F. (1990). The phyletic relationships of extant and fossil Pitheciinae (Platyrrhini, Anthropoidea). J. Hum. Evol. 19: 175-208.

Kimura, M. (1980). A simple method for estimating evolutionary rate of base substitution through comparative studies of nucleotide sequences. J. Mol. Evol. 16: 111-120.

Koiffmann, C.P. and Saldanha, P.H. (1974). Cytogenetics of Brazilian monkeys. J. Hum. Evol. 3: 275-282.

Lawn, R.M., Efstratiadis, A., O'Connell, C. and Maniatis, T. (1980). The nucleotide sequence of the human $\beta$-globin gene. Cell 21: 647651.

Lebo, R.V., Carrano, A.V., Burkhart-Schultz, K., Dozy, A.M., Yu, L.C. and Kan, Y.W. (1979). Assignment of the human $\beta$-, $\gamma$-, and $\delta$-globin genes to the short arm of chromosome 11 by chromosome sorting and DNA restriction enzyme analysis. Proc. Natl. Acad. Sci. USA 76: 5804-5808.

Lima, M.M.C. and Seuánez, H.N. (1991). Chromosome studies in the red howler monkey, Alouatta seniculus stramineus (Platyrrhini, Primates): description of an X1X2Y1Y2/X1X1X2X2 sex chromosome system and karyological comparisons with other subspecies. Cytogenet. Cell Genet. 57: 151-156.

Meireles, C.M. (1997). Molecular evolution of gamma 1 and gamma 2 globin genes in atelines (Primates, Platyrrhini). PhD thesis, Universidade Federal do Pará, PA, Brasil.
Meireles, C.M., Schneider, M.P.C., Sampaio, M.I.C., Schneider, H., Slightom, J.L., Chiu, C.-H., Neiswanger, K., Gumucio, D.L., Czelusniak, J. and Goodman, M. (1995). Fate of a redundant $\gamma$ globin gene in the atelid clade of New World monkeys: implications concerning fetal globin gene expression. Proc. Natl. Acad. Sci. USA 92: 2607-2611.

Meireles, C.M., Czelusniak, J., Schneider, M.P.C. and Goodman, M. (1998). Hemoglobina fetal: estrutura, expressão e evolução do gene gama em primatas (Primates, Platyrrhini). In: Série Monografias No. 6 (Duarte, F.A.M., ed.). Sociedade Brasileira de Genética, Ribeirão Preto, pp. 1-27.

Meireles, C.M., Czelusniak, J., Schneider, M.P.C., Muniz, J.A.P.C., Brigido, M.C., Ferreira, H.S. and Goodman, M. (1999). Molecular phylogeny of ateline New World monkeys (Platyrrhini, Atelinae) based on $\gamma$-globin gene sequences: evidence that Brachyteles is the sister group of Lagothrix. Mol. Phylogenet. Evol. 12: 10-30.

Mittermeier, R.A., Rylands, A.B. and Coimbra-Filho, A.F. (1988). Systematics: species and subspecies - an update. In: Ecology and Behavior of Neotropical Primates. Vol. 2 (Mittermeier, R.A., Rylands, A.B., Coimbra-Filho, A.F. and da Fonseca, G.A.B., eds.). World Wildlife Fund, Washington D.C., pp. 13-75.

Napier, J.R. and Napier, P.H. (1967). A Handbook of Living Primates. Academic Press, New York.

Neville, M.K., Glander, K.E., Braza, F. and Rylands, A.B. (1988). The howling monkeys, genus Alouatta. In: Ecology and Behavior of Neotropical Primates. Vol. 2 (Mittermeier, R.A., Rylands, A.B., CoimbraFilho, A.F. and da Fonseca, G.A.B., eds.). World Wildlife Fund, Washington D.C., pp. 349-453.

Pargament, M.D.M., Vinuesa, M.L.L., Colillas, O.J. and Salum, S.B. (1984). Banding patterns of Alouatta caraya. Rev. Bras. Genét. VII: 373-379.

Porter, C.A., Sampaio, I., Schneider, H., Schneider, M.P.C., Czelusniak, J. and Goodman, M. (1995). Evidence on primate phylogeny from $\varepsilon$-globin gene sequences and flanking regions. J. Mol. Evol. 40: 3055 .

Porter, C.A., Czelusniak, J., Schneider, H., Schneider, M.P.C., Sampaio, I. and Goodman, M. (1997a). Sequences of the primate $\varepsilon$-globin gene: implications for systematics of the marmosets and other New World primates. Gene 205: 59-71.

Porter, C.A., Page, S.L., Czelusniak, J., Schneider, H., Schneider, M.P.C., Sampaio, I. and Goodman, M. (1997b). Phylogeny and evolution of selected primates as determined by sequences of the $\varepsilon$-globin locus and 5' flanking regions. Int. J. Primatol. 18: 261-295.

Rogan, P.K., Pan, J. and Weissman, S.M. (1987). L1 repeat elements in the human $\varepsilon^{-}{ }^{\mathrm{G}} \gamma$-globin gene intergenic region: sequence analysis and concerted evolution within this family. Mol. Biol. Evol. 4: 327-342.

Rosenberger, A.L. (1984). Fossil New World monkeys dispute the molecular clock. J. Hum. Evol. 13: 737-742.

Rylands, A.B. and Brandon-Jones, D. (1998). Scientific nomenclature of the red howlers from the northeastern Amazon in Brazil, Venezuela, and the Guianas. Int. J. Primatol. 19: 879-905.

Sambrook, J., Fritsch, E.F. and Maniatis, T. (1989). Molecular Cloning: A Laboratory Manual. 2nd edn. Cold Spring Harbor Laboratory Press, Cold Spring Harbor, New York.

Sanger, F., Nicklen, S. and Coulson, A.R. (1977). DNA sequencing with chain-terminating inhibitors. Proc. Natl. Acad. Sci. USA 74: 54635467.

Schneider, H. and Rosenberger, A.L. (1996). Molecules, morphology, and platyrrhine systematics. In: Adaptive Radiations of Neotropical Primates (Norconk, M.A., Rosenberger, A.L. and Garber, P.A., eds.). Plenum Press, New York, pp. 3-19.

Schneider, H., Schneider, M.P.C., Sampaio, I., Harada, M.L., Stanhope, M., Czelusniak, J. and Goodman, M. (1993). Molecular phylogeny of the New World monkeys (Platyrrhini, Primates). Mol. Phylogenet. Evol. 2: 225-242.

Schneider, H., Sampaio, I., Harada, M.L., Barroso, C.M.L., Schneider, M.P.C., Czelusniak, J. and Goodman, M. (1996). Molecular phylogeny of the New World monkeys (Platyrrhini, Primates) based on two unlinked nuclear genes: IRBP intron 1 and $\varepsilon$-globin sequences. Am. J. Phys. Anthropol. 100: 153-179.

Shen, S.-H., Slightom, J.L. and Smithies, O. (1981). A history of the hu- 
man fetal globin gene duplication. Cell 26: 191-203.

Shoshani, J., Groves, C.P., Simons, E.L. and Gunnell, G.F. (1996). Primate phylogeny: morphological vs. molecular results. Mol. Phylogenet. Evol. 5: 102-154.

Slightom, J.L., Blechl, A.E. and Smithies, O. (1980). Human fetal ${ }^{\mathrm{G}} \boldsymbol{\gamma}$ - and ${ }^{A} \gamma$ - globin genes: complete nucleotide sequences suggest that DNA can be exchanged between these duplicated genes. Cell 21: 627-638.

Slightom, J.L., Koop, B.F., Xu, P. and Goodman, M. (1988). Rhesus fetal globin genes: concerted gene evolution in the descent of higher primates. J. Biol. Chem. 263: 12427-12438.

Stanyon, R., Tofanelli, S., Morescalchi, M.A., Agoramoorthy, G., Ryder, O.A. and Weinberg, J. (1995). Cytogenetic analysis shows exten- sive genomic rearrangements between red howler (Alouatta seniculus, Linnaeus) subspecies. Am. J. Primatol. 35: 171-183.

Tagle, D.A., Koop, B.F., Goodman, M., Slightom, J.L., Hess, D.L. and Jones, R.T. (1988). Embryonic $\varepsilon$ and $\gamma$ globin genes of a prosimian primate (Galago crassicaudatus): nucleotide and amino acid sequences, developmental regulation and phylogenetic footprints. $J$. Mol. Biol. 203: 439-455.

Yunis, E.J., Caballero, O.M.T., Ramirez, C. and Ramirez, Z.E. (1976). Chromosomal variation in the primate Alouatta seniculus seniculus. Folia Primatol. 25: 215-224.

(Received September 3, 1998) 